\title{
ТРАНСПОРТ И ТРАНСПОРТНЫЕ ОБЯЗАТЕЛЬСТВА ПО ЗАКОНОДАТЕЛЬСТВУ РОССИЙСКОЙ ФЕДЕРАЦИИ
}

\section{TRANSPORT AND TRANSPORT OBLIGATIONS UNDER THE LEGISLATION OF THE RUSSIAN FEDERATION}

\section{El. Tumanov}

Summary: This article deals with problematic issues of legal regulation of transport and transport obligations. Judicial practice is studied, the importance and continuity of the volitional and mental components of the process of implementing the right in transport obligations is noted. Problematic issues are considered: the «weak side» of contractual relations for transportation, insufficient legal regulation of the carsharing agreement. A comparative description of the rental agreement and the carsharing agreement is carried out.

Keywords: transport, transport obligations, contract, party, rights and obligations, carsharing, transportation, responsibility, law.
$\mathrm{B}$ опросы оптимального правового регулирования транспорта и транспортных обязательств в настоящее время все также актуальны как в отдельно взятом субъекте $\mathrm{PФ}$, так и в целом в рамках всего государства. Так, как указывает Н.М. Конин, ссылаясь на ст. 71 Конституции Российской Федерации [1], транспорт, пути сообщения и дорожное хозяйство относится к предмету ведения Российской Федерации, «а на органы исполнительной власти субъектов Российской Федерации согласно их конституциям, законам, уставам возлагается решение вопросов транспортного обслуживания населения» [3. С. 25].

Таким образом, можно отметить, что регулирование сферы транспортного обслуживания населения преимущественно осуществлялось и осуществляется региональными органами исполнительной власти. В свою очередь, гражданским законодательством РФ выделяются определенные виды договорных отношений в области транспортных обязательств (в частности, это договоры, возникающие вследствие перевозок грузов и пассажиров (ст. 785 и ст. 786 ГК РФ [2]), фрахтования (ст. 787 ГК РФ), транспортной экспедиции (ст. ст. 801 - 806 ГК РФ)) и т.д.

Полагаем, что некоторые вопросы их правового регулирования содержат проблемные моменты, которые нами и будут рассмотрены в настоящей статье. Так, считаем возможным говорить о том, что в конкретном гражданском правоотношении, например, по перевоз-
Туманов Эльдар Валерьевич

К.ю.н., дочент, Российский университет транспорта, 2. Москва,

tumanov_roat_dot@bk.ru

Аннотация: В настоящей статье рассмотрены проблемные вопросы правового регулирования транспорта и транспортных обязательств. Исследована судебная практика, отмечена важность и неразрывность волевого и умственного компонента процесса осуществления права в транспортных обязательствах. Рассмотрены проблемные вопросы: «слабой стороны» договорных отношений по перевозке, недостаточного правового регулирования договора каршеринга. Проведена сравнительная характеристика договора проката и договора каршеринга.

Ключевые слова: транспорт, транспортные обязательства, договор, сторона, права и обязанности, каршеринг, перевозка, ответственность, закон.

ке груза, может возникнуть проблема в части признания слабой стороной как одного субъекта договора, так и другого. Данный вопрос уже неоднократно поднимался в научной литературе.

Так, С.Ю. Морозовым обосновывалась позиция о том, что грузоотправитель, в силу слабой защищенности, является слабой стороной договора железнодорожной перевозки грузов [4. С. 188]. В связи с чем нам представляется интересным нижеуказанные материалы судебной практики.

Рассмотрим судебное решение штата Индии, в котором грузополучатель предъявляет иск компании, осуществляющей железнодорожную перевозку грузов. Суть иска заключается в следующем: истец получил груз частично без содержимого, в своем требовании он указал, что сумма компенсации, предоставляемой компанией, его не устраивает и условия перевозки, указанные на обороте квитанции, он не видел. Однако суд постановил, что квитанция содержит формулировку «смотрите на обороте условия» и потому вопрос о не предоставлении информации об условиях заявлен в требованиях быть не может. Более того, суд указал, что даже без вышеуказанной формулировки на обороте квитанции вопрос о привилегиях грузополучателя как слабой стороны в силу его глупости, невежества или беспечности снимается, поскольку разумно ожидать, что компания, осуществляющая перевозку грузов, должна проинформировать грузополучателя, а тот, в свою очередь, должен осведо- 
миться об условиях компании при получении квитанции [4. C. 189].

Кроме того, достаточно часто субъекты становятся слабой стороной ввиду отсутствия необходимой информации. Так, рассмотрим иск по возмещению морального ущерба пассажиру, путешествующему с семьей, предъявленный компании-перевозчику United Airlines. На борту самолета произошел следующий инцидент. Стюардесса потребовала у пассажира убрать сумку с щенком породы французский бульдог на верхнюю багажную полку салона самолета. Полет продолжался 3,5 часа, по прилете щенок был найден мертвым и не подлежал реанимированию. В суде излагались две причины невозможности извлечения собаки из багажного отсека:

- во-первых, во время полета самолет находился в постоянной зоне турбулентности и пассажирам не разрешалось вставать;

- во-вторых, стюардесса рассматривается как авторитетная фигура, которая имеет возможность подавлять поведение и волю пассажира.

Также отмечалось незнание пассажиром правил перевозки животных, установленных авиакомпанией, согласно которым животное весом до 8 кг можно провозить в салоне самолета в специальных клетке или сумке, с учетом того что собака не бойцовской породы и не составляет угрозы жизни и здоровью человека [6].

Иск был удовлетворен, так как было установлено, что потребитель испытывал нравственные страдания.

Таким образом, вышеприведенные примеры наглядно показывают важность и неразрывность волевого и умственного компонента процесса осуществления права в транспортных обязательствах, так как в вышеприведенной ситуации имеет место подавление волеизъявления слабой стороны - потребителя контрагентом и недостаточное владение информацией первым. По нашему мнению, разрешению указанной проблемы будет способствовать четкое определение законодателем случаев, когда «слабость» контрагента вызвана объективными факторами, а когда они отсутствуют. Кроме того, данное решение проблемы позволит установить дополнительные механизмы защиты слабой стороны транспортного обязательства.

Разрешая указанные проблемы, законодатель должен четко определить, в каких случаях «слабость» контрагента вызвана объективными факторами, а когда таковые отсутствуют.

Помимо вышеизложенного отметим и появившиеся в недавнее время новые виды транспортных обязательств. Полагаем, что их правовое регулирование в настоящее время не совершенно. В частности, на практике до сих пор отсутствует четкое правовое регулирование договора каршеринга.

В результате анализа статистических данных можно с уверенностью утверждать, что, если даже использовать только один подобный автомобиль, то с улиц «уйдет» 15 частных машин, будет освобождено 20 парковочных мест. Вследствие чего повсеместное и систематическое использование данного сервиса сократит выброс углекислого газа на 15\%, а скорость городского движения повысится на 60\% [5. С. 53]. Рассматривая динамику использования каршеринга в Москве можно отметить ее увеличение, поскольку в 2018 г. с помощью каршеринга было совершено 23 миллиона поездок, а в январе 2019 г. - уже около 2,7 миллиона [7].

По нашему мнению, определить транспортные обязательства, вытекающие из договора каршеринга, можно как разновидность договора проката, поскольку для данных договоров характерны определенные признаки, а именно:

1. В части юридической квалификации рассматриваемых договорных отношений, они являются: консенсуальными, возмездными, взаимными, публичными (вместе с тем, отдельными каршеринговыми компаниями договор каршеринга не признается публичным).

2. В части предмета договоров: предметом является предоставление конкретного транспортного средства во временное владение и пользование.

3. В части субъектного состава: арендодателем выступает прокатная организация (являющаяся юридическим лицом или индивидуальным предпринимателем), а арендатором является физическое лицо.

4. В части цели заключения договора: арендодатель желает получить прибыль, а арендатор имеет потребительскую цель.

5. В части прав и обязанностей сторон транспортного обязательства: обязанностью арендодателя является осуществление капитального и текущего ремонта транспортного средства.

6. В части возможности субаренды арендатор не вправе: передавать свои права и обязанности иным лицам, предоставлять автомобиль в безвозмездное пользование, залог и т.д.

Вместе с тем, следует обозначить и различия между договором проката и договором каршеринга:

1. В части формы договора: для договора проката обязательна письменная форма договора (п. 2 ст. 626 ГК РФ), а каршеринг заключается через мобильное приложение и в электронной форме.

2. В части срока договора. Договор проката предусматривает передачу автомобиля во временное владение и пользование на определенный срок, 
не превышающий 1 года (п. 1 ст. 627 ГК РФ). Договор каршеринга может быть заключен как на несколько минут, так и на несколько часов.

3. В части арендной платы: для договора проката она установлена в виде определенных в твердой сумме платежей, которые должны вноситься единовременно или периодически (п. 1 ст. 630 ГК РФ), наличным или безналичным расчетом. В свою очередь, договор каршеринга предусматривает поминутный расчет арендной платы и оплату с банковской карты.

В завершение сделаем вывод о том, что существующие в настоящее время транспортные правоотношения и вытекающие из них транспортные обязательства требуют не только дополнительного научного осмысления, но и дополнительного правового урегулирования.

\section{ЛИТЕРАТУРА}

1. Конституция Российской Федерации (принята всенародным голосованием 12.12.1993 с изменениями, одобренными в ходе общероссийского голосования 01.07.2020) // СПС «Консультант Плюс».

2. Гражданский кодекс Российской Федерации (часть вторая) от 26.01.1996 N 14-Ф3 (ред. от 27.12.2019, с изм. от 28.04.2020) // С3 РФ. 1996. N 5. С. 410.

3. Конин Н.М., Маторина Е.И. Административное право России:Учебник. М., 2019. С. 25.

4. Морозов С.Ю. Система транспортных организационных договоров. М., 2011. С. 188.

5. Москаленко А. Коллективный транспорт // Бизнес-журнал. 2016. N 9. С. 53.

6. Sherry F. Colb. United Airlines and the Milgram Experiment. 28 Mar 2018. URL: https://verdict.justia.com/ (дата обращения: 20.09.2020).

7. Официальный сайт мэра Москвы. URL: https://www.mos.ru/news/item/53039073/?utm_source=yxnews\&utm_medium=desktop (дата обращения: 20.09.2020).

○ Туманов Эльдар Валерьевич (tumanov_roat_dot@bk.ru).

Журнал «Современная наука: актуальные проблемы теории и практики»

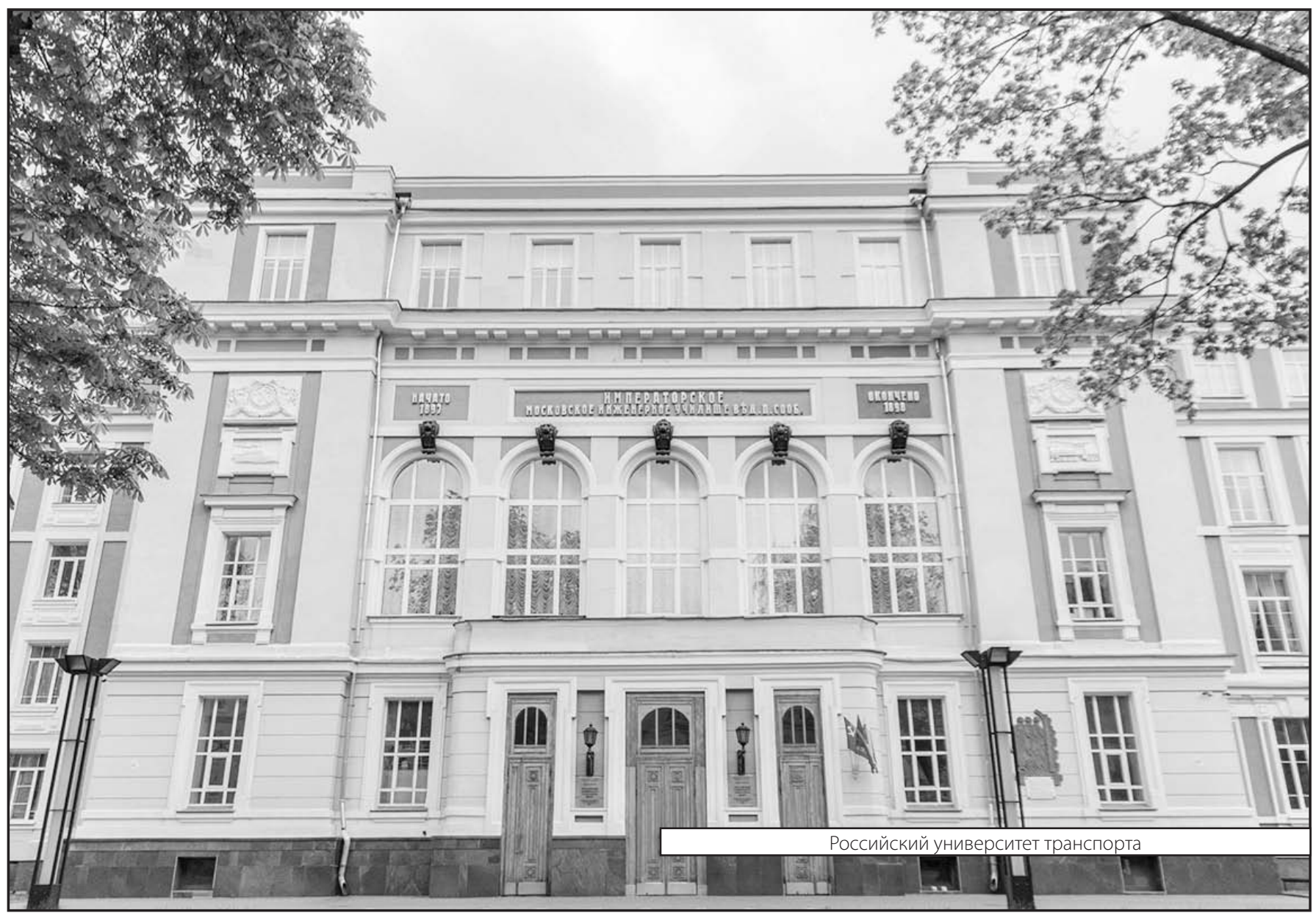

